\title{
Synchronous acceleration of ice loss and glacial erosion, Glaciar Marinelli, Chilean Tierra del Fuego
}

\author{
Michèle KOPPES, ${ }^{1}$ Bernard HALLET, ${ }^{2}$ John ANDERSON ${ }^{3}$ \\ ${ }^{1}$ Department of Geography, University of British Columbia, 1984 West Mall, Vancouver, British Columbia V6T 1Z2, Canada \\ E-mail: koppes@geog.ubc.ca \\ ${ }^{2}$ Department of Earth and Space Sciences and Quaternary Research Center, Box 351310, University of Washington, Seattle, \\ Washington 98195-1310, USA \\ ${ }^{3}$ Department of Earth Science, Rice University, 6100 Main Street, Houston, Texas 77005, USA
}

\begin{abstract}
To contribute to the understanding of the influence of climate on glacial erosion and on orogenic processes, we report contemporary glacial erosion rates from a calving glacier in the Southern Andes and elucidate the influence of ice dynamics on erosion. Using seismic profiles of sediments collected in a proglacial fjord and a documented history of retreat, we determine the time-varying sediment flux of Glaciar Marinelli as a measure of basin-wide erosion rates, and compare these rates with the annual ice budget reconstructed using NCEP-NCAR reanalysis climate data from 1950 to 2005. The rate of erosion of the largest tidewater glacier in Tierra del Fuego averaged $39 \pm 16 \mathrm{~mm} \mathrm{a}^{-1}$ during the latter half of the 20th century, with an annual maximum approaching $130 \mathrm{~mm} \mathrm{a}^{-1}$ following a decade of rapid retreat. A strong correlation emerges between the variable rate of ice delivery to the terminus and the erosion rate, providing quantitative insight into the relationship between ice fluxes and glacial erosion rates. For Glaciar Marinelli, as for other calving glaciers for which suitable data exist, the marked retreat and thinning over the past 50 years have resulted in a period of accelerated basal sliding and unusually rapid erosion.
\end{abstract}

\section{INTRODUCTION}

Several recent studies have documented the close correspondence between the peak elevations of an orogen and the perennial snowline elevation (Montgomery and others, 2001; Mitchell and Montgomery, 2006), supporting the hypothesis that higher rates of erosion in glacial and periglacial environments effectively limit the elevation of mountain ranges (e.g. Porter, 1981; Brozović and others, 1997). Rapid glacial and periglacial erosion creates in effect a 'snow buzz saw' whereby only limited crustal material can rise above a certain elevation, often defined as the equilibrium-line altitude (ELA), regardless of the rate of rock uplift. The buzz-saw hypothesis is tantalizing, in particular because it suggests that a lowering of the ELA during cold periods would increase the area subjected to glacial and periglacial processes, thereby accelerating erosion.

Our ability to assess the snow buzz-saw hypothesis and other aspects of the interplay between tectonics, climate and topography has been limited to date by a dearth of data both quantifying basin-scale glacial erosion rates and linking such rates to pertinent glacier characteristics. Compiling data from the limited studies that have empirically determined the rate of basin-wide erosion for a number of glaciers (e.g. Powell, 1991; Harbor and Warburton, 1993), Gurnell and others (1996) and Hallet and others (1996) both demonstrated that sediment yields (as a measure of basinwide erosion) from glaciated basins range from $<10^{-3}$ to $>10^{-2} \mathrm{~m} \mathrm{a}^{-1}$. In general, sediment yields from the rapidly eroding large glaciated basins significantly exceeded those from glacier-free basins of comparable size. However, neither compilation addressed what controls these rapid glacial erosion rates or the significant variations within and between glacier basins, for most of the sediment yield studies were conducted with little attention to the glaciers themselves, or to inter-basin differences in climate or bedrock resistance to erosion. Moreover, many of the studies were focused on a small subset of glaciers in Alaska and northern Europe, chosen for ease of access. Hence, they may not be representative of most glaciers.

Much of our current understanding of both the dynamics of tidewater glaciers and the tempo of glacial erosion originates in the coastal mountains of Alaska, USA (e.g. Meier and Post, 1987; Powell, 1991; Humphrey and Raymond, 1994; Van der Veen, 1996; Koppes and Hallet, 2002, 2006; Sheaf and others, 2003). The relationship between glacial erosion and tectonics is also being addressed in this region (e.g. Meigs and Sauber, 2000; Gulick and others, 2004; Spotila and others, 2004; Berger and Spotila, 2008). Koppes and Hallet (2002) suggested that the tidewater glaciers in Alaska have been unusually dynamic and erosive since the end of the Little Ice Age (LIA), when regional warming caused rapid terminus retreat and the drawdown of hundreds of meters of ice over the past century. The acceleration in ice flow required to evacuate such immense volumes of ice from the basins is inferred to result in accelerated basal sliding. Due to unusually fast sliding, recent erosion rates are likely to far exceed those over the long term.

Comparing measurements of glacial erosion rates and the response of tidewater glaciers to climate in other regions permits us to assess and improve the empirical relationships between glacier dynamics and erosion developed in Alaska, and to explore whether these relationships are universal. The icefields of Patagonia and Tierra del Fuego are two of the last remaining regions of substantial ice cover aside from the polar ice sheets.

Herein, we present one of the first studies of basin-wide rates of contemporary glacial erosion in the Southern Andes, and investigate the relationship between sediment yields over time and the dynamic state of Glaciar Marinelli, 


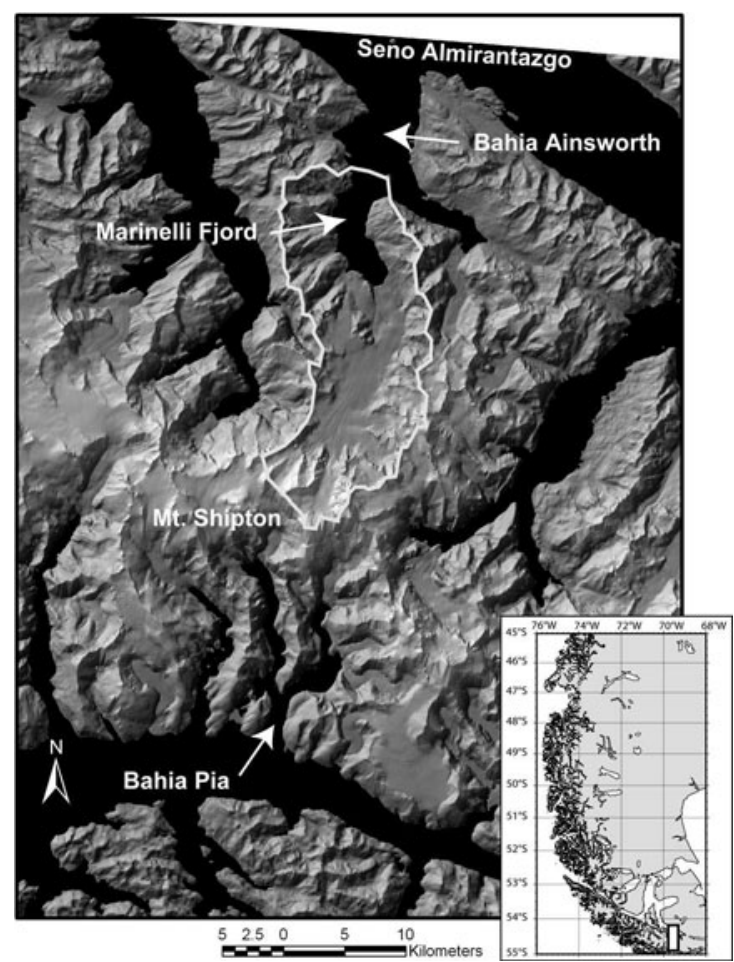

Fig. 1. Location map of Glaciar Marinelli, Chilean Tierra del Fuego, South America, with shaded-relief representation of a DEM of Glaciar Marinelli and its fjord, derived from February 2001 Shuttle Radar Topography Mission (SRTM) data. Glacier basin in 1945 is outlined in white.

Chilean Tierra del Fuego (Fig. 1). We first define the volume of sediment delivered by Glaciar Marinelli and accumulated in a proglacial fjord since the start of the most recent phase of rapid retreat during the latter half of the 20th century. From the measured sediment distribution and historical records of terminus retreat, we model the sediment yield of the glacier on an annual basis. We then analyze this sediment yield, converted to a basin-averaged erosion rate, in the context of a simple volume budget of glacial ice reconstructed using key regional climate variables over the past 50 years and a digital elevation model (DEM) of the glacier surface. This ice budget quantifies gains and losses of ice, enabling us to estimate the time-varying glacier flux, which we infer exerts significant control on erosion rates, and helps us probe climatic and non-climatic controls on both terminus retreat and glacial erosion.

The rest of the paper is structured in three parts after outlining the regional setting. Section 3 describes the methods used for, and discusses the results of, the sediment yield analysis. Section 4 outlines the methodology used and discusses the results of the ice-volume budget model. Section 5 explores the relationship between the erosion rates derived in section 3 and the rates of ice motion estimated in section 4 .

\section{REGIONAL SETTING}

\subsection{Location and geology}

The Cordillera Darwin icefield covers the southwestern region of Tierra del Fuego, where the mountains exceed $2000 \mathrm{~m}$ in elevation and trend northwest to southeast for approximately $120 \mathrm{~km}$, peaking at Monte Shipton
(2469 ma.s.I.; also known as Monte Darwin). The range is approximately $50 \%$ ice-covered. Although the $2300 \mathrm{~km}^{2}$ of the icefield is mostly contiguous, steep topography and structural constraints confine most of the ice masses within individual catchments.

Glaciar Marinelli, the largest glacier in the Cordillera Darwin, drains the northern flanks of Monte Shipton and calves into a fjord directly south of Bahia Ainsworth, an arm of Seno Almirantazgo to the northeast of the range (Fig. 1). Located at $54^{\circ} 32^{\prime} \mathrm{S}, 69^{\circ} 35^{\prime} \mathrm{W}$, the glacier is approximately $21 \mathrm{~km}$ long, with a basin area in 2005 of $154 \mathrm{~km}^{2}$. Until the mid-20th century, the glacier terminus was stable at the mouth of the fjord, pinned on an arcuate terminal moraine that marks the LIA advance of the glacier (Porter and Santana, 2003), with a $\sim 4 \mathrm{~km}$ wide ice front calving directly into shallow water in Bahia Ainsworth. The calving terminus in 2005 was $1.8 \mathrm{~km}$ wide, with an average ice-cliff height above waterline of $45 \mathrm{~m}$.

The bedrock of the region is comprised of meta-sediments and meta-volcanics, intruded by small batholiths (Dalziel and Cortés, 1972). Soil cover is sparse, and often limited to the moraines. The vegetation is dominated by young forest of southern beech (Nothofagus betuloides and Nothofagus Antarcticus) and canelo (Drymis winterii). The mouth of Bahia Ainsworth opens into Seno Almirantazgo (Fig. 1), one of the deepest basins along a chain of en echelon depressions along the Magallanes-Fagnano transform (MFT) system (Diraison and others, 1997). The MFT is one of several prominent west-east-trending strike-slip faults that experienced significant motion in the mid- to late Holocene and as recently as 1949 (Rabassa and others, 1992; Bentley and McCulloch, 2005).

\subsection{Regional climate}

Meteorological gradients across the Cordillera Darwin are steep, with heavy precipitation and solid cloud cover being typical over the southern and western fjords, and drier conditions to the north and east (Holmlund and Fuenzalida, 1995; Porter and Santana, 2003). Automated weather stations recently deployed by the University of Magallanes show annual precipitation averages of $1600 \mathrm{~mm}$ at Bahia $\mathrm{Pia}$, in the southern part of the range, dropping to $800 \mathrm{~mm}$ at Seno Almirantazgo, just north of Marinelli fjord (personal communication from A. Santana, 2005). Precipitation, mostly in the form of snowfall, falls mainly in the spring and is associated with westerly and southwesterly winds that pick up moisture from the cool Humboldt current offshore, although the coldest air masses arrive from the south (US National Centers for Environmental Prediction (NCEP)-US National Center for Atmospheric Research (NCAR) dataset; Kalnay and others, 1996; Schneider and Gies, 2004).

Long-term climate stations in Tierra del Fuego are scant and discontinuous, limited to Chilean Navy lighthouses on the west coast, and the few towns in the region (Puerto Williams, Punta Arenas, Ushuaia) that have been inhabited for more than a century. The few climate stations that have operated for more than a decade show large variability in precipitation over short distances, as weather masses are forced over the narrow spine of the mountains (e.g. Rosenblüth and others, 1995; Schneider and Gies, 2004). Due to such high spatial variability, records from stations nearby may not accurately represent local conditions on the glaciers, particularly since all the stations in the region are located at sea level and in the lee of the major mountain 
a

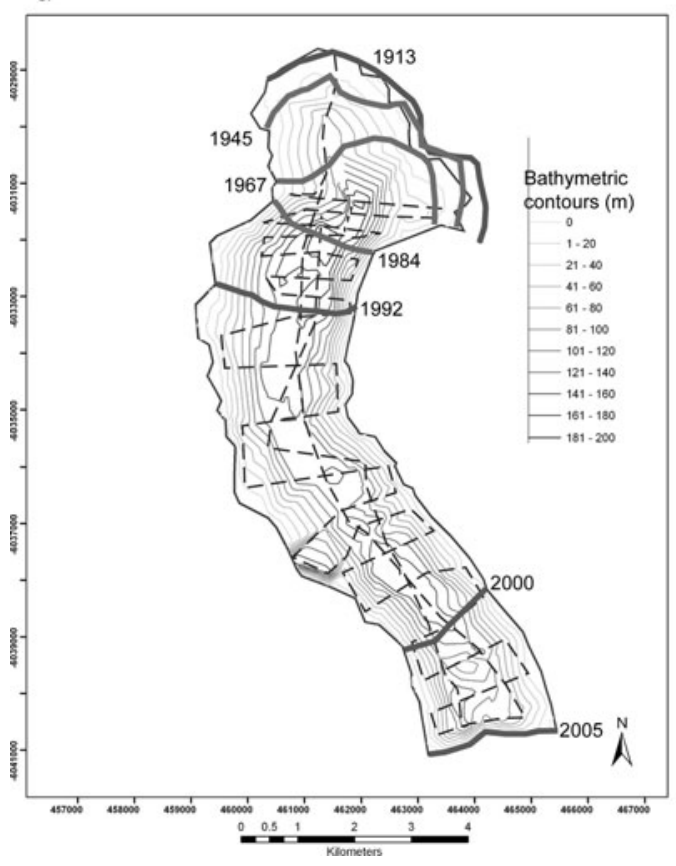

b

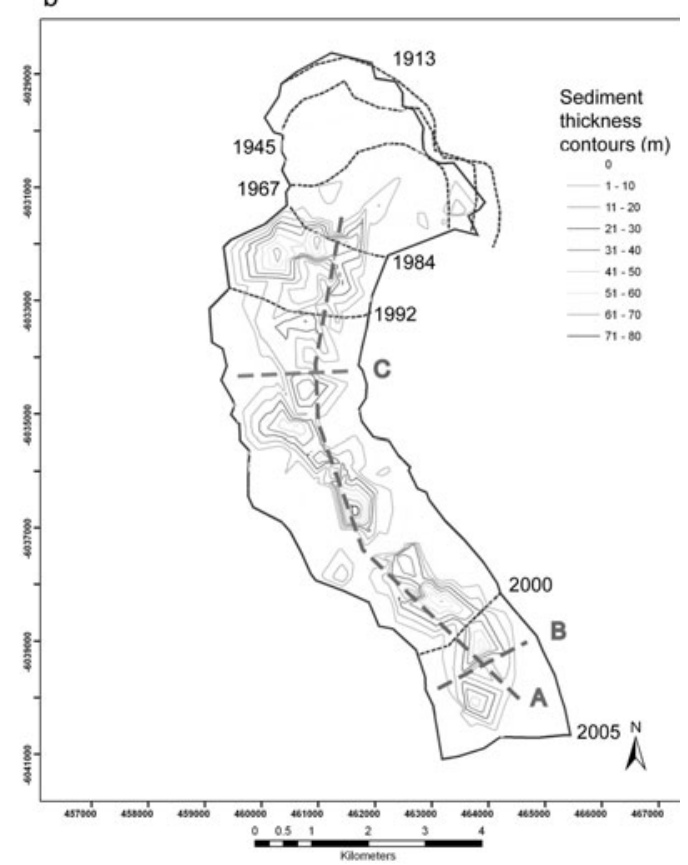

Fig. 2. (a) Contour map of 2005 bathymetry in Marinelli fjord (20 m interval), track lines of the acoustic reflection survey (dashed black lines) and known terminus positions since 1913 (grey curves). (b) $10 \mathrm{~m}$ contours of glacimarine sediment thickness in Marinelli fjord, derived from the acoustic reflection profiles, and locations of seismic profiles (A-C, dashed grey curves) in Figure 4.

ranges, where they are sheltered from the renowned Patagonian winds.

Climate records at Bahia Felix and Punta Arenas, $220 \mathrm{~km}$ and $180 \mathrm{~km}$ to the west and northwest of Marinelli fjord, show a slight decrease in annual precipitation starting in 1920 (Holmlund and Fuenzalida, 1995), but no significant change in seasonality. Records from Punta Arenas and Puerto Williams (135 km to the southeast) also indicate a sustained regional warming since 1915 and a relatively dry period around Tierra del Fuego in the mid-1960s (Porter and Santana, 2003).

\subsection{Retreat of Glaciar Marinelli}

Glaciar Marinelli was first visited during a 1913 expedition by G.B. De Gasperi and A. De Agostini, who observed the glacier filling the fjord and abutting the arcuate terminal moraine, with a steep surface profile near the ice front descending sharply from $\sim 140$ ma.s.l. (Porter and Santana, 2003). The glaciated basin area at that time exceeded $252 \mathrm{~km}^{2}$; it has since decreased to $158 \mathrm{~km}^{2}$ in 2005. According to a United States Air Force (USAF) aerial photo taken in 1945, the glacier started to recede from the moraine around this time into steadily deepening water $(>210 \mathrm{~m}$ in the center of the fjord) and began retreating rapidly, revealing a fjord $13 \mathrm{~km}$ long within a few decades. A series of seven aerial photographs and satellite images document the gradually accelerating retreat (Porter and Santana, 2003; Fig. 2a). Since the mid-1980s, the terminus has retreated hundreds of meters per year, with a peak rate exceeding $1 \mathrm{~km} \mathrm{a}^{-1}$ in the late 1990s. The western half of the terminus receded onto bedrock above sea level $\sim 9 \mathrm{~km}$ from the LIA moraine in the late 1990s; the remaining tidewater terminus has pulled back another $3.5 \mathrm{~km}$ in the eastern half of the fjord. The glacier surface has also thinned considerably: trimlines can be traced from $\sim 60$ m a.s.l. at the fjord mouth to around $250 \mathrm{~m}$ a.s.l. at the 2005 glacier terminus (Fig. 3).
The dramatic recession of Glaciar Marinelli in the latter half of the 20th century is in stark contrast to the general pattern of standstill or minor recession of calving and non-calving glaciers around the Cordillera Darwin (Holmlund and Fuenzalida, 1995), and in particular to the slow advance of the south-facing glaciers of Bahia Pia, which drain the other side of Monte Shipton (personal communication from C. Porter, 2006).

Holmlund and Fuenzalida (1995) first documented the exceptional retreat of Glaciar Marinelli, noting that a relatively warm 20th century may have caused significant thinning of the glacier tongue through ablation, while the glacier continued to be grounded on the terminal moraine. When the glacier front thinned sufficiently in the latter half of the century, the ice broke up quickly and the front retreated rapidly. Porter and Santana (2003) also documented the retreat of Glaciar Marinelli in the latter half of the 20th century, and compared the timing of retreat to the climate record at Punta Arenas, surmising that decades of negative mass balance in the first half of the 20th century led to significant surface thinning and eventually initiated the rapid retreat in the mid-1960s. Both studies suggest that this rapid retreat was induced by the local submarine topography, as the glacier front receded into deep water. That the glacier surface continued to maintain a significant slope since 1960, as captured in aerial photos, indicates that the entire glacier tongue was grounded during 45 years of retreat; a floating tongue would have resulted in a nearly level glacier terminus slope.

\section{GLACIAL EROSION RATES}

\subsection{Methods}

To define the sediment yield from Glaciar Marinelli, and to examine how it varied while both climate and glacial extent 


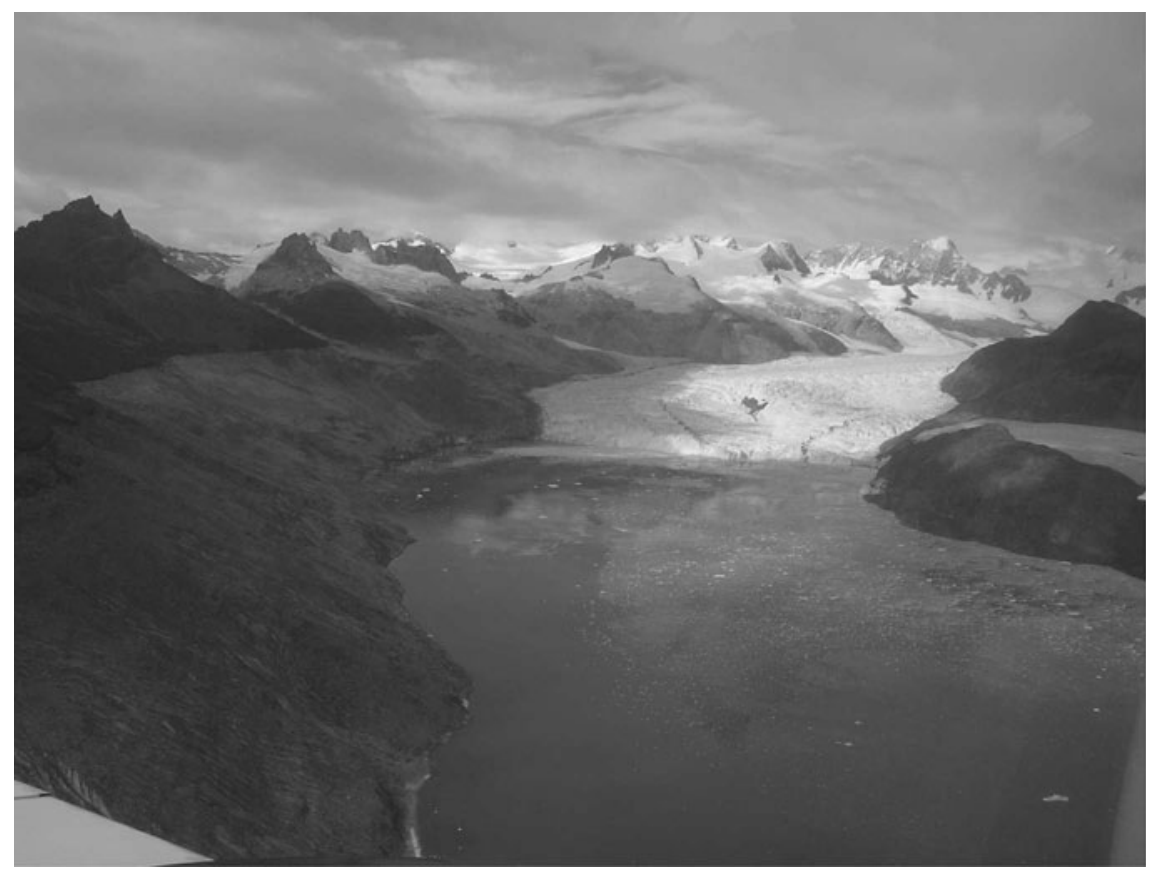

Fig. 3. March 2005 view of the inner fjord and calving terminus of Glaciar Marinelli, looking south. Note the high trimlines on the valley wall to the left of the terminus.

varied in the latter half of the 20th century, seismic reflection profiles of the postglacial sediment volume were collected in Marinelli fjord in July 2005. A 300J Boomer and 1000J Sparker transducer with a Benthos hydrophone streamer were used, firing at $0.2-0.5 \mathrm{~s}$. Both transducers penetrated the soft sediment in the fjord bottom and imaged a strong, nonpenetrable reflector at up to $100 \mathrm{~m}$ below the sediment surface. In quantifying the postglacial sediment volumes, we assume that during the last advance, in the LIA, the glacier evacuated all non-consolidated sediments collected in the fjord bottom above this reflector, which most likely represents either (1) the bedrock surface or (2) the top of proglacial sediments that were overridden and compacted by advancing ice. The former seems more likely as the reflector rises along the sides of the fjord and emerges as bedrock above the waterline (Fig. 4). Regardless, any seismically semi-transparent sediment above this reflection was assumed to be deposited after the overlying ice retreated.

The postglacial sediment package is well defined in the seismic record as two distinct facies over the strong reflector: a semi-transparent, laminated layer interpreted to be predominantly ice-distal glaciomarine input with minor eolian and fluvial contributions, and a hummocky, chaotic facies presumed to be ice-proximal sediments and/or submarine slumps. Both facies are typical of deposits in temperate, tidewater fjords (e.g. Molnia and others, 1984; Stravers and others, 1992; Anderson, 1999). The hummocky, chaotic facies is limited to the base of the steep fjord walls and the edges of bedrock highs in the center of the fjord. Sediment in Marinelli fjord primarily consists of fines that rained out from the water column, or were mobilized and reworked by strong bottom currents to produce the well-laminated, nearhorizontal layers filling a string of basins.

To convert two-way travel time in the water to depth, an average seismic velocity of $1460 \pm 6 \mathrm{~m} \mathrm{~s}^{-1}$ in the brackish fjord waters was used, based on Seacat CTD (conductivitytemperature-depth) profiler measurements close to the ice front and in the center of the fjord. The postglacial sediment thickness and depth to bedrock in the fjord were reconstructed along a dense set of seismic profiles along and across the fjord (Fig. 2a), using a median seismic velocity of $1680 \mathrm{~m} \mathrm{~s}^{-1}$ for glaciomarine sediments (Stoker and others, 1997). From the seismic profiles, both the bathymetry and the subsurface bedrock elevations in the fjord were interpolated between ship tracks using the triangulated-irregularnetwork (TIN) function in ArcGIS. The TIN layers of the prominent bedrock reflector and the sediment surface were then rasterized into $60 \mathrm{~m} \times 60 \mathrm{~m}$ grids, and the sediment volume was calculated as the difference between the sediment surface and basal reflector (Fig. 2b).

To determine the uncertainty in the sediment thickness measurements, we compared the original measured depths from the seismic profiles with the gridded depths at the same locations, using the leave-one-out cross-validation method. The interpolation and gridding introduce at most an $18 \%$ error in total sediment thickness, with the magnitude of the error increasing with both distance between tracks and spatial variability in the depths and sediment thicknesses. Adding in a user error of $\sim 10 \mu \mathrm{s}$, or $1-2 \%$, in picking sediment depths from the seismic profiles, and another $\pm 5 \%$ error in assuming the median seismic velocity for glacimarine muds, the total error in determining the fjord sediment volume from the seismic profiles is estimated to be $25 \%$.

This estimate of total sediment volume in the fjord, divided by the time since the glacier last occupied the fjord, yields the flux of sediment from Glaciar Marinelli into the fjord, averaged over the period of retreat. The sediment flux, however, and by inference the erosion rate, probably varied significantly during this retreat, a period when the ice flux must have varied substantially due to rapidly changing glacier and fjord geometries and climate. To examine this temporal variation in sediment flux, we used a numerical model of time-dependent proglacial sedimentation (de- 

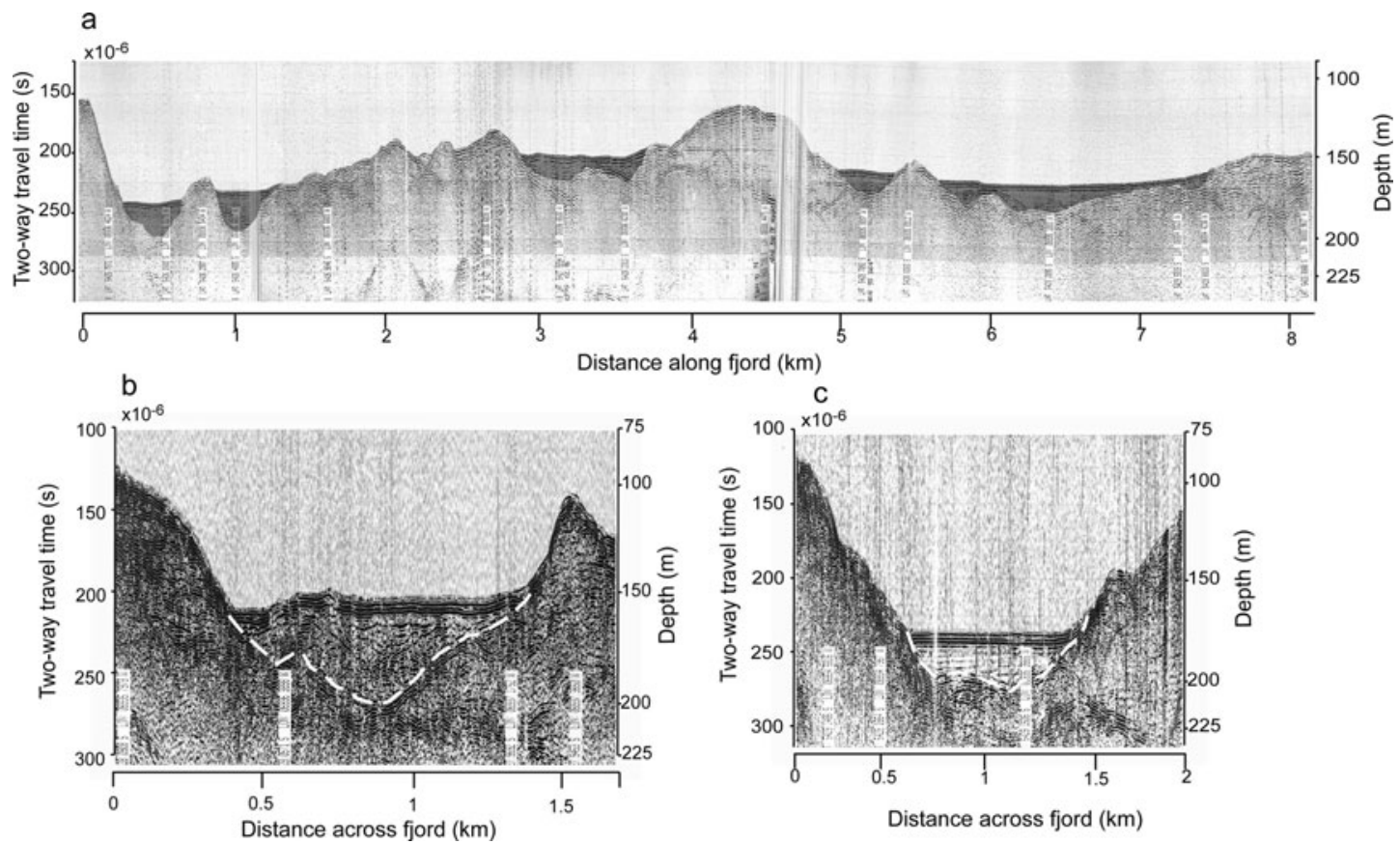

Fig. 4. Examples of acoustic reflection profiles from which the sediment thickness in Marinelli fjord was measured: (a) longitudinal profile along the thalweg from the foot of the terminal moraine (left) to approximately $1 \mathrm{~km}$ from the ice front (right) (glacimarine sediment is shaded dark grey); and (b, c) transverse profiles $2 \mathrm{~km}$ from the 2005 ice front (b) and close to the 1992 terminus position (c). We interpret the semitransparent, laminated seismic facies, filling in the deeper basins, to be ice-distal glacimarine sediments, and the hummocky, chaotic seismic facies near bedrock highs as ice-proximal deposits and submarine slumps. The top of the underlying crystalline bedrock appears as the dominant reflective layer (highlighted by dashed white line) beneath the other facies.

scribed by Koppes and Hallet, 2002). In this model, we assume that the thickness of the proglacial sedimentary package at any location in a fjord reflects a combination of two independent, glacially modulated processes: the rate of sediment delivery to the terminus and the rate of terminus retreat. The model enables us to reconstruct the history of sediment delivery from measured sediment thickness profiles and a known history of retreat. We calculate the sediment flux necessary to produce the observed volume of sediment in the fjord on an annual basis, given independent data documenting the rate of terminus retreat, interpolated between known terminus positions using a cubic spline function. The sediment flux is converted to a basin-wide sediment production rate per unit area by dividing the flux by the glacier basin area during that period, and assuming that changes in subglacial and supraglacial storage of the sediment are not significantly modulating the sediment output; this important assumption is discussed further in section 3.3. The sediment production rate is then multiplied by the ratio between the density of glaciomarine sediment $\left(1.8 \mathrm{~g} \mathrm{~cm}^{-3}\right.$ out of a range of $\left.1.7-2.0 \mathrm{~g} \mathrm{~cm}^{-3}\right)$ and crystalline bedrock $\left(\sim 2.7 \mathrm{~g} \mathrm{~cm}^{-3}\right)$ to determine the basin-wide bedrock erosion rate. This poorly constrained range of densities introduces a subsequent uncertainty in the calculation of the bedrock erosion rate of up to $12 \%$, so that the cumulative effective error in the calculated basin-wide erosion rates approaches $37 \%$.

The proglacial sedimentation model incorporates the transport and deposition of glacially derived sediment as a function of distance from the ice front, as debris rains out of both the calving front and the turbid plumes that rise buoyantly at the ice front and flow away from the terminus (Syvitski, 1989). The model also represents the post- depositional sediment redistribution along the fjord bottom by gravity flows and other mass transfers. Constraints on the variation in the rate of sedimentation with distance from the terminus are therefore needed, at least in simplified form, to reconstruct the temporal variation in sediment yield from the glacier. To date, only a few empirical studies of the variation in proglacial sedimentation rates have been conducted in front of temperate tidewater glaciers (e.g. Syvitski, 1989; Cowan and Powell, 1991); these studies all suggest that sedimentation rates decrease exponentially with distance from the ice front.

Sedimentation rates were measured with three sets of sediment traps deployed within $1 \mathrm{~km}$ of the terminus of Glaciar Marinelli; the traps collected near-bottom sediments for 1 week in July 2005 . The sedimentation rate, $S\left(\mathrm{~m} \mathrm{a}^{-1}\right)$, on the sea floor decreased exponentially with distance, $x(\mathrm{~m})$, from the ice front, much as Syvitski (1989) has reported for other fjords:

$$
S=0.046 \mathrm{e}^{-0.0003 x}\left(r^{2}=0.99\right) .
$$

Although the sedimentation rates we measured are only representative of mid-winter rates, when subglacial meltwater plumes are expected to be least active, the form of the decrease in sedimentation with distance from the ice front is assumed to be representative of all seasons, and is used in the sedimentation model.

\subsection{Glacial erosion rates since 1960}

Based on the acoustic reflection survey of Marinelli fjord, $>3.9 \times 10^{8} \mathrm{~m}^{3}$ of sediment have been deposited in the fjord since about 1960, when the glacier retreated from the LIA moraine (Fig. 2b). The bulk of the sediment has collected in a string of interconnected basins along the thalweg of the 
a

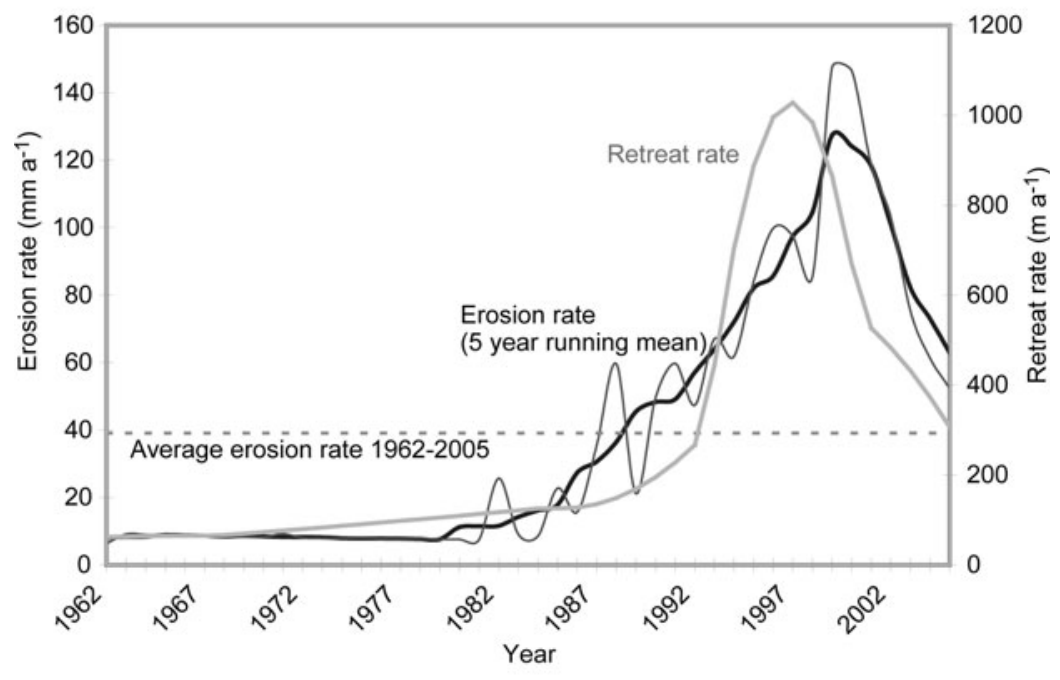

b

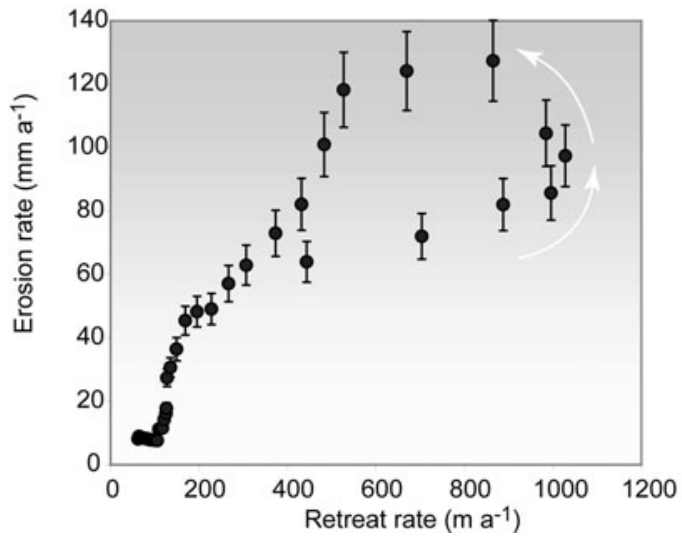

Fig. 5. (a) Time-series comparison of erosion rate and retreat rate for Glaciar Marinelli since 1962. The contemporary erosion rate averages $39 \pm 12 \mathrm{~mm} \mathrm{a}^{-1}$. (b) Comparison of erosion and retreat rates. Error bars represent a 38\% uncertainty for calculated erosion rates. A hysteresis loop emerges, a function of the time lag between the peak in retreat rate and the peak in erosion rate. Extrapolating the erosion rate to times when the glacier is effectively stable, on average neither advancing nor retreating, the long-term erosion rate is $10 \pm 3 \mathrm{~mm} \mathrm{a}^{-1}$.

fjord. They are, in general, separated by transverse bedrock ribs, with little if any sediment on the crest of the ribs (Fig. 4).

There is essentially no indication, subaerially or in the submarine record, of sediment of non-glacial origin slumping from the valley walls and contributing substantially to the sediment accumulation in the fjord. Trimlines from the LIA advance are high and distinct, with few signs of rilling that would reflect substantial subaerial erosion and redeposition of glacial or non-glacial sediments into the fjord following retreat. There are no subaerial deltas forming at the waterline, and only one of the three small tributary streams entering the fjord formed a small submarine delta. This delta was excluded from the glaciomarine sediment volume estimate, and other non-glacial, subaerial sources of sediment were not considered further, as they account for no more than a few percent of the postglacial sediment volume in the fjord.

The glacier front pulled back completely from the LIA moraine between 1945 and 1967 (Fig. 2). Since the exact timing of this event is unknown, we assume the glacier retreated the $\sim 2 \mathrm{~km}$ from the crest to the up-fjord foot of the LIA moraine at a constant rate, and pulled away from the foot of the moraine around 1960. We further assume that all laminated and semi-transparent sediments imaged in the fjord bottom were deposited between 1960 and 2005 . Dividing the total sediment volume, $3.9 \times 10^{8} \mathrm{~m}^{3}$, by this 45 years since retreat from the moraine foot, the sediment flux into the fjord over this period averaged $(0.87 \pm 0.3) \times 10^{7} \mathrm{~m}^{3} \mathrm{a}^{-1}$. Dividing this flux by the average basin area, which decreased by $>40 \%$ during the period 1960-2005, the estimated basin-wide bedrock erosion rate from Glaciar Marinelli during the latter half of the 20th century averaged $39 \pm 16 \mathrm{~mm} \mathrm{a}^{-1}$.

The sediment flux computed on an annual basis, using our model of proglacial sedimentation (Koppes and Hallet, 2002), can be divided by the steadily decreasing drainage area of the glaciated basin to estimate the time-varying basin-averaged erosion rate (Fig. 5). This erosion rate varies greatly from year to year, roughly in parallel with the interpolated rate of retreat from 1960 to 2005. For the first 20 years it averaged $9 \mathrm{~mm} \mathrm{a}^{-1}$, and steadily increased, starting in 1982, up to a peak of almost $130 \mathrm{~mm} \mathrm{a}^{-1}$ in 2000. It subsequently decreased to $65 \mathrm{~mm} \mathrm{a}^{-1}$ in 2005 . Similarly, the retreat rate increased from $100 \mathrm{ma}^{-1}$ in the 1960s and 1970s to $>1000 \mathrm{ma}^{-1}$ in 1996, then slowly decreased back to $300 \mathrm{~m} \mathrm{a}^{-1}$ in 2005 . 
Given that our time-varying sedimentation model treats the total thickness of sediment in a fjord as a function of both the changing rate of sediment delivery to the terminus and the rate of retreat, it is prudent to examine whether the correlation between erosion and retreat rates we are finding may be affected, in part, due to a circularity of reasoning. Indeed, our analysis appears sound, as it effectively normalizes the thickness of proglacial sediments for the retreat rate so that we can determine the sediment flux and the corresponding erosion rate as functions of time. The need for this normalization is evident from the following example. If the sediment flux from a retreating glacier varied randomly in time, the thickness of the resulting proglacial sediment package would also vary randomly in time but it would tend to be systematically thinner along reaches of the fjord where retreat was rapid, because the sediment would be spread out over the broader area uncovered by the rapid retreat. Without accounting for the time-varying retreat, this tendency would bias the sediment flux inferred from sediment thickness; the flux would be underestimated for reaches traversed rapidly by the retreating terminus. Our model enables us to remove this bias, and to examine quantitatively the temporal variation of the sediment flux required to produce the observed sediment package given the known retreat history. In effect, the modeled erosion rate increases with the observed sediment thickness normalized for variations in retreat rates, and adjusted for submarine mass wasting and redeposition.

The sediment yields we are measuring represent subglacial erosion as well as any sediment delivered to the glacier surface by periglacial processes in the basin, or stored beneath the glacier and subsequently entrained and transported to the fjord. Because over two-thirds of the basin is covered by ice, and the portion above the glacier surface is steep and covered with a perennial mantle of snow, there is little space for subaerial stores to contribute substantially to the sediment delivered to the fjord. The vast volume of sediment delivered to Marinelli fjord over the past 45 years also suggests that changes in subglacial sediment storage cannot solely account for the sediment yield, as that would require the removal of a layer of basal debris $>20 \mathrm{~m}$ thick under the entire ablation area of the glacier, where the subglacial debris is most likely to collect. Such a layer of subglacial debris far exceeds characteristic basal sediment thicknesses, $\sim 0.5 \mathrm{~m}$, measured beneath temperate tidewater glaciers in similar climatic settings (Kamb and others, 1985; Humphrey and others, 1993). Hence, the sediment produced closely reflects active subglacial erosion over the past 50 years. On an annual timescale, however, this sediment could result from a decrease in subglacial sediment storage and it may reflect lags in the delivery of sediment from sites of bedrock erosion and sediment storage to the terminus. At Glaciar Marinelli, the peak in retreat rate appears to lead the peak in sediment flux and inferred erosion rate by $\sim 2$ years, suggesting a lag between the processes controlling retreat of the ice front and those accelerating sediment delivery to the glacier front.

\subsection{Implications of sediment yields and retreat on basal sliding}

The close correlation at Glaciar Marinelli between the sediment yield and retreat rate of the ice front has also been documented at two Alaskan tidewater glaciers (Koppes and Hallet, 2002, 2006), prompting us to consider what under- lies this correlation. One obvious cause for the covariance of the sediment yield and retreat rate could arise from englacial sediment delivered to the terminus and released directly into the fjord. This delivery is the product of the rate of ice lost from the terminus and the volumetric concentration of debris in the ice, so that as ice is lost during retreat, the rate at which englacial sediment melts out of the ice will tend to co-vary with retreat rate. The dearth of debris visible in the ice cliffs at the terminus, on the surface of the glacier and in the multitude of icebergs that clog the fjord indicates, however, that the englacial debris concentration in Glaciar Marinelli is far too low to produce the large volumes of sediment imaged in the fjord. Assuming the debris concentration in Glaciar Marinelli is similar to that for visibly 'dirtier' Alaskan tidewater glaciers, where supraglacial and englacial debris amounts to at most $1 \%$ per unit volume of ice calving from the terminus (Hunter and others, 1996), the total volumetric contribution of entrained sediment flux from meltout from the ice lost from the terminus is at most $10 \%$ of the sediment volume delivered by the glacier over the study period. In other words, the average ice speeds required to deliver the sediment fluxes observed solely through englacial entrainment are clearly unrealistic; they exceed $10-20 \mathrm{~km} \mathrm{a}^{-1}$ for decades. The debris entrained in the glacier hence cannot account for the large sediment yields from Glaciar Marinelli, and importantly, such high yields could not be sustained without concomitant bedrock erosion.

Instead, we propose as before (Koppes and Hallet, 2006), and will further examine quantitatively, that retreat and erosion rates are closely correlated at Glaciar Marinelli because rapid ice motion is characteristic of retreating calving glaciers, as recognized in Alaska and Greenland (e.g. Van der Veen, 1996; Howat and others, 2005; Luckman and others, 2006). An increase in ice speed, especially due to faster sliding, would tend to increase sediment yields, through accelerated bedrock erosion and evacuation of sediments stored under the glacier. The importance of ice speed on glacial sediment yields was first demonstrated by Humphrey and Raymond's (1994) study of Variegated Glacier, Alaska, where a two-orders-of-magnitude variation in sediment yield accompanied a similar variation in ice speed over a glacier surge cycle. For this glacier, sediment yields were correlated with surface and sliding speeds. An increase in erosion rate with sliding speed is entirely in accord with theoretical models in which both abrasion and quarrying rates increase with sliding speeds (Hallet, 1979, 1996).

Based on these theoretical grounds and empirical results from the Variegated Glacier study and from a similar study at Bench Glacier, Alaska, (Riihimaki and others, 2005) basinwide averaged glacial erosion rates are expected to scale with the characteristic basal sliding speed. For temperate, fast-moving glaciers, such as Variegated Glacier and Columbia Glacier, Alaska, basal sliding accounts for essentially all of the ice motion (Kamb and others, 1994); hence, sliding speeds can be directly related to the ice flux of the glacier. Besides its simplicity, the advantage of using ice flux in considerations of erosion is that it can be related to net accumulation and ablation on the glacier surface over time, and hence to local climate through precipitation rates and temperature. This permits exploration of how basin-wide erosion rates might vary due to variations in climate over time and space for many temperate calving glaciers even 
where ice speeds and ice thickness have not been measured, such as on Glaciar Marinelli.

The correlation between sediment fluxes and retreat rates suggests that unusually large ice fluxes associated with the rapid retreat of Glaciar Marinelli over the past 45 years have induced unusually rapid erosion of the basin. To explore this relationship further, we examine temporal variations in the volume of ice flowing through the glacier during this period, as a generalized index of sliding speed, and compare them with the temporal variations in observed erosion rates.

\section{ICE BUDGET MODEL}

\subsection{Estimating the ice flux through Glaciar Marinelli over the past 50 years}

For this region, where no direct measurements of ice thickness or velocity have ever been made and climate records are sparse, we reconstruct the ice budget for the glacier using the NCEP-NCAR global reanalysis climate dataset, sparse local environmental data, the history of terminus positions and other geologic data. Dictated by the conservation of ice, the ice budget through a calving glacier can be expressed as:

$$
\frac{\mathrm{d} L}{\mathrm{~d} t}=\frac{Q_{\mathrm{bal}}+Q_{\mathrm{thin}}-Q_{\mathrm{calv}}}{A_{\text {term }}},
$$

where $\mathrm{d} L / \mathrm{d} T$ is the change in glacier length, $Q_{\text {bal }}$ is the surface mass balance (the net ice volume input from precipitation per year, i.e. the snowfall accumulation minus ablation integrated over the glacier area), and $Q_{\text {thin }}$ is the annual glacier volume reduction due to thinning. The rate of ice loss at the terminus, $Q_{\text {calv, }}$ includes both calving and melting averaged over the changing area of the terminus face, $A_{\text {term. }}$. A glacier is in balance when $Q_{\text {calv }}$ equals $Q_{\text {bal, }}$ and neither the glacier thickness nor length is changing. For a glacier in retreat, the ice volume decreases through glacier shortening $Q_{\text {term }}=-(\mathrm{d} L / \mathrm{d} T) A_{\text {term }}$ and lowering of the glacier surface, $Q_{\text {thin. }}$ In this context, $Q_{\text {thin }}$ effectively adds to the ice delivered to and calved from the terminus. As $\mathrm{d} L / \mathrm{d} T$ can be measured from known terminus positions, $A_{\text {term }}$ measured from the fjord bathymetry and approximate terminal ice-cliff height $(\sim 40 \mathrm{~m}), Q_{\text {thin }}$ derived from indicators of surface lowering such as trimlines, and $Q_{\text {bal }}$ derived from local climate parameters (precipitation and temperature), it is useful to reorganize Equation (2) to solve explicitly for the calving flux $Q_{\text {calv, }}$ which is effectively the volume of ice passing through the terminus per unit time:

$$
Q_{\text {calv }}=Q_{\text {bal }}+Q_{\text {thin }}+Q_{\text {term }} \text {. }
$$

Any variability in this calving flux, averaged over the terminus cross-sectional area $A_{\text {term, }}$ can be inferred to represent temporal changes in the cross-sectionally averaged ice velocity and, hence, in the characteristic basal sliding speed (see below).

To derive the surface mass balance $Q_{\text {bal }}$ of Glaciar Marinelli over the past 50 years, local precipitation and temperature conditions at the glacier were reconstructed from the NCEP-NCAR reanalysis climate dataset (Kalnay and others, 1996; Kistler and others, 2001), a Web-accessed, daily updated backcast global dataset based on radiosonde and sea-level pressure measurements coupled to atmospheric physics. The NCEP-NCAR model reconstructs multiple climate parameters at geopotential heights throughout the troposphere on a $1.9^{\circ} \times 1.9^{\circ}$ grid providing, amongst other parameters, daily near-surface temperature, zonal and meridional wind speeds, snowfall and precipitation rates at each gridpoint. The nearest gridpoint to Glaciar Marinelli in the NCEP model is at $54.285^{\circ} \mathrm{S}, 69.375^{\circ} \mathrm{W}, 27 \mathrm{~km}$ to northnorthwest. We use the climate variables at this gridpoint to reconstruct to first order the daily and yearly accumulation and ablation of ice over the surface of the glacier, and to model the annual ice budget for Glaciar Marinelli through the last 50 years.

Due to its low spatial resolution, the NCEP-NCAR model is unable to resolve local topographic influences such as that of the Cordillera Darwin, which is $<40 \mathrm{~km}$ wide, on the precipitation of the region. The regional NCEP record was thus compared to local conditions at Glaciar Marinelli determined using rain and temperature gauges installed on the LIA moraine at the mouth of the fjord from July 2005 to April 2006. The comparison enables us to assess the NCEP record and seek local calibration (Fig. 6). The following regressions were obtained between measured values and NCEP-NCAR model values:

$$
\begin{aligned}
T_{\mathrm{MAR}}= & 0.65 T_{\mathrm{NCEP}}+2.11 \\
& \left(r^{2}=0.70, n=279, P<0.0001\right) \\
P_{\mathrm{MAR}}= & 1.01 P_{\mathrm{NCEP}}-0.28 V_{\mathrm{NCEP}}+1.19 \\
& \left(r^{2}=0.28, n=279, P=0.0002\right),
\end{aligned}
$$

where $T_{\text {MAR }}$ and $T_{\text {NCEP }}$ are the average daily temperatures $\left({ }^{\circ} \mathrm{C}\right)$ from the gauge and NCEP record respectively, $P_{\text {MAR }}$ and $P_{\text {NCEP }}$ are the daily gauge and NCEP precipitation rates $\left(\mathrm{mm} \mathrm{d}^{-1}\right)$ and $V_{\text {NCEP }}$ is the mean daily meridonal wind speed $\left(\mathrm{m} \mathrm{s}^{-1}\right)$ from the NCEP dataset. Each regression was then applied to the daily NCEP record at the nearest gridpoint for the period 1950-2004 to estimate precipitation and temperature at the glacier terminus during the $>50$ years preceding the deployment of our gauges.

A strong correlation between precipitation rates and NCEP wind speeds in the region was noted by Schneider and Gies (2004). With dominant westerly flow of wind and moisture wrapping around Cape Horn and arriving at Glaciar Marinelli from the southwest to northwest, precipitation rates at Glaciar Marinelli appear to be most influenced by the magnitude of meridonal winds (north-south); we therefore included the meridonal wind strength $\left(V_{\text {NCEP }}\right)$ in the precipitation rate regression to strengthen the correlation (adding $V_{\text {NCEP }}$ increased $r^{2}$ from 0.19 to 0.28 ). We note that while the reanalysis data capture the timing of larger rainfall events accurately, they appear to systematically underestimate the magnitude of larger storm events by as much as a factor of 4 (Fig. 6), and hence calibration with locally measured precipitation values remains relatively poor $\left(r^{2}=0.28\right)$. Applying a 10 day averaging improved the correlation only slightly $\left(r^{2}=0.34\right)$. Therefore, while using the NCEP dataset from 1950-2005 (calibrated to local conditions to model accumulation) captures the temporal variations in ice flux, it may systematically underestimate the magnitude of the accumulation component in our ice budget model.

The NCEP-NCAR reanalysis temperature data at geopotential heights of 1000,925, 850, 700 and 600 mbar were used to calculate the daily vertically averaged lapse rate, from which the elevation of the snowline on the glacier could be determined. The environmental lapse rate for the gridpoint nearest Glaciar Marinelli, which averaged $6.01^{\circ} \mathrm{C} \mathrm{km}^{-1}$, was used with the reconstructed local daily average temperature 

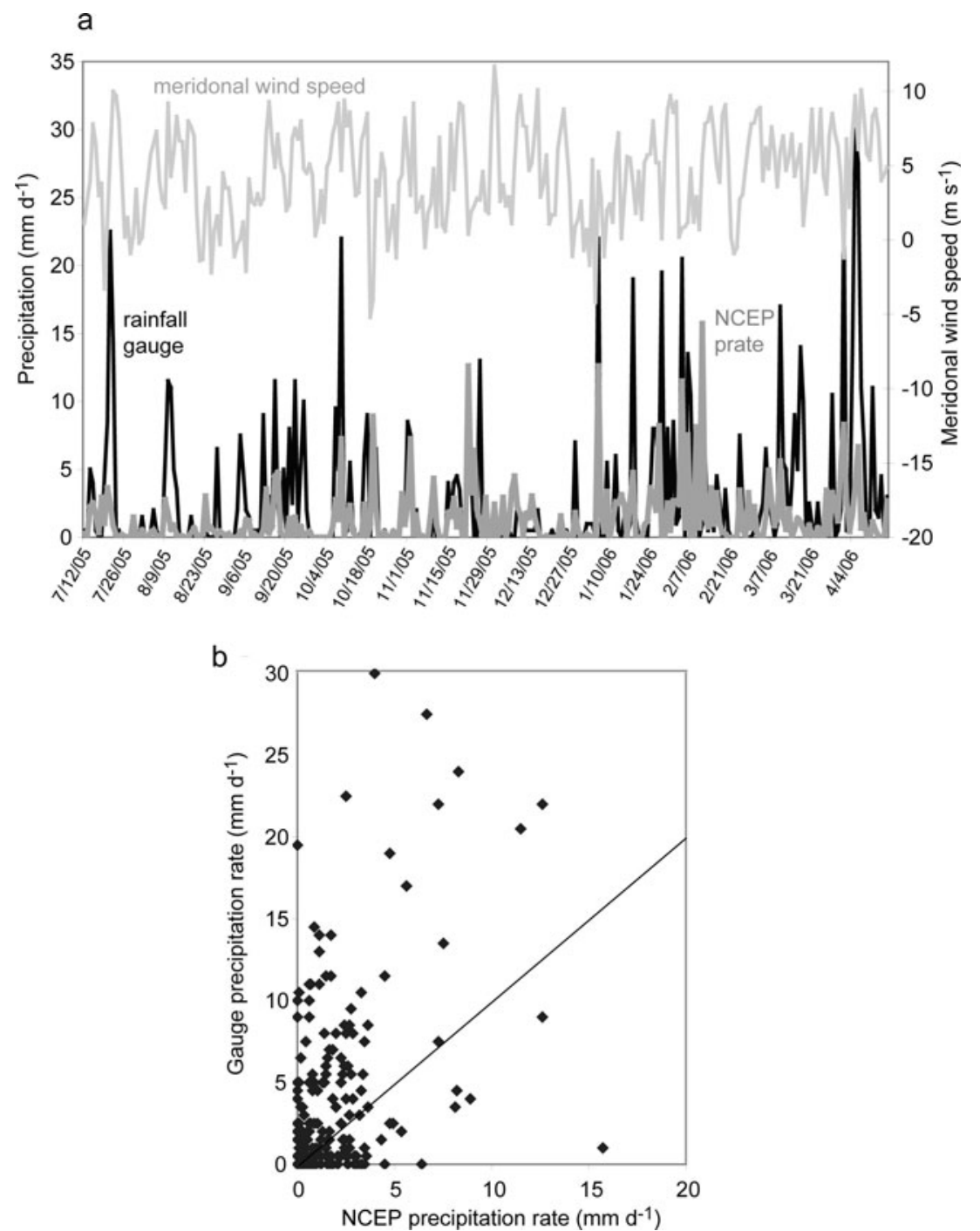

Fig. 6. Comparison of surface precipitation rates from the NCEP reanalysis dataset for gridpoint $54.675^{\circ} \mathrm{S}, 69.375^{\circ} \mathrm{W}$, and rainfall from gauges installed at the mouth of Marinelli fjord, July 2005-April 2006. (a) Time series of NCEP precipitation (dark grey curve) and gauge precipitation (black curve), in $\mathrm{mm} \mathrm{d}^{-1}$, with surface meridonal wind speeds (light grey curve) in $\mathrm{ms}^{-1}$. Dates are month/day/year. (b) Comparison plot of NCEP and gauge rainfall rates.

at the terminal moraine ( $\sim 6 \mathrm{~m}$ a.s.I.) to locate the elevation of the $2{ }^{\circ} \mathrm{C}$ isotherm on the glacier surface. We then computed the total snow input (w.e. per unit time) to the glacier, assuming all precipitation above this elevation in the drainage basin fell as snow into the contributing drainage basin $\left(189 \mathrm{~km}^{2}\right.$ in 2005) obtained from a $30 \mathrm{~m}$ DEM generated from NASA's Shuttle Radar Topography Mission in 2001 (Fig. 1). The reconstructed precipitation rates at sea level were enhanced three-fold to represent, to first order, the influence of orography on snowfall on the glacier, based on similar observations of a three-fold increase in accumulation between coastal climate stations and the summit plateaux of the adjacent Patagonian icefields, to the north (Escobar and others, 1992; Carrasco and others, 2002). Imposing an enhancement factor of 3 , out of a range of plausible values for orographic enhancement (1.5-4; personal communication from A. Santana, 2005), introduced a maximum estimated uncertainty in $Q_{\text {acc }}$ of $\sim 50 \%$.

To estimate ablation rates $\left(Q_{\text {abl }}\right)$ on Glaciar Marinelli, we used the nearest available record of ablation and associated climate, which is at Glaciar Lengua in the Gran Campo Nevado (Schneider and others, 2007), $285 \mathrm{~km}$ to the northwest. Glaciar Lengua receives moisture from the same westerly and southwesterly storms that impinge on the Cordillera Darwin, and the cold Humboldt Current running up the western shelf of Patagonia also similarly influences air temperature. Ablation stakes were placed in the lower reaches of the glacier during the summer of 1999/2000 and measured daily. Daily air temperatures were also collected at a nearby refuge at $30 \mathrm{~m}$ a.s.l. The regional ablation rate, $\alpha$ $\left(\mathrm{mm} \mathrm{d}^{-1}\right)$, correlated well with local daily average air temperature, $T_{\text {avg }}\left({ }^{\circ} \mathrm{C}\right)$, near sea level (Fig. 7):

$\alpha=7.42 T_{\text {avg }}-23.96 \quad\left(r^{2}=0.99 ; n=182 ; P<0.0001\right)$.

This correlation was then applied to the surface of Glaciar Marinelli $\left(A_{\mathrm{gl}}\right)$ to calculate the daily ablation rate at each elevation as a function of the locally calibrated NCEP temperature and lapse rate, and summed to calculate the annual ice volume lost through ablation: $\int \alpha(t) A_{\mathrm{gl}} \mathrm{d} t$.

To assess whether our model adequately represents the snow input and mass-balance fluxes for Glaciar Marinelli in the absence of direct glaciological observations, we focus on 


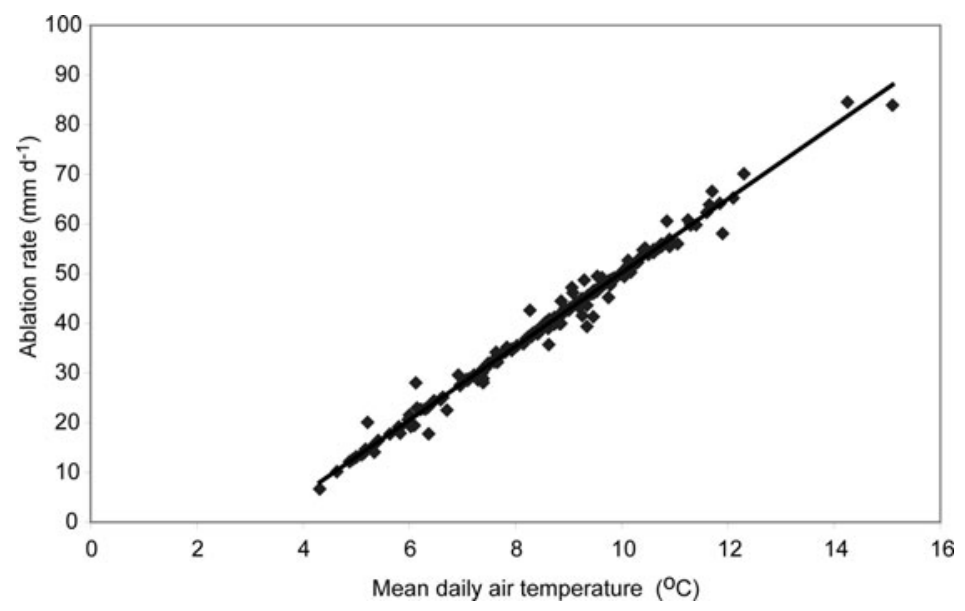

Fig. 7. Ablation rate in $\mathrm{mm} \mathrm{d}^{-1}$ vs local mean daily temperature, Glaciar Lengua (data from Schneider and others, 2007).

the period 1950-60, when the ice front was relatively stationary. Given that the glacier was relatively stable (i.e. volume essentially constant, wherein $Q_{\text {bal }}=Q_{\text {calv }}$ and $Q_{\text {thin }}=0$ ) during this period, the ice flux reaching the terminus and corresponding rate of ice motion can be estimated from the inferred balance between ice sources (the annual snow input, $Q_{\text {acc }}$ ) and sinks (the annual ablation, $Q_{\text {abl }}, Q_{\text {calv }}$ ) in the ice budget model (see Equation (3) and Fig. 8a). It is estimated that the ice flux at the terminus, $Q_{\text {calv, }}$ during the period 1950-60 approached $0.2-0.4 \mathrm{~km}^{3} \mathrm{a}^{-1}$. The corresponding cross-sectionally averaged calving speeds, estimated by dividing $Q_{\text {calv }}$ by the terminus cross-sectional area $A_{\text {term }}$ (Fig. 8b) during this stable period, averaged 500$1200 \mathrm{~m} \mathrm{a}^{-1}$ across a $\sim 4 \mathrm{~km}$ wide terminus that was grounded in $\sim 60 \mathrm{~m}$ of water on the terminal moraine and formed an exposed ice cliff averaging $40 \mathrm{~m}$. Observations at a number of glaciers in Alaska, Greenland and Svalbard suggest that for a calving margin grounded in $60 \mathrm{~m}$ of water, calving speeds average between $550 \mathrm{~m} \mathrm{a}^{-1}$ (Pelto and Warren, 1991) and $1.6 \mathrm{~km} \mathrm{a}^{-1}$ (Brown and others, 1982). That our estimate of the calving flux at Glaciar Marinelli is within the range of observed tidewater calving rates for this period gives us confidence in our estimates of ice input and output over a $\sim 50$ year period, even in the absence of local environmental and glaciological measurements. We stress that significant uncertainties remain in the climate input parameters due both to uncertainties in the orographic enhancement factor, and poor correlation between the local climate and the NCEP precipitation results.

\subsection{Climatic influences on Glaciar Marinelli and its erosion rate}

According to our locally calibrated NCEP-NCAR climate model results, both precipitation and temperature have contributed to an increasingly negative mass balance over the past 50 years, with steadily decreasing inputs of snow onto the glacier, and increasing loss of ice due to ablation (Fig. 8a). Precipitation at Glaciar Marinelli decreased, with considerable variability, from the 1950s until the present. In the 21 st century, precipitation remained at almost half the precipitation in 1960. Moreover, temperatures have risen steadily since the 1950s; since 1997, they have remained more than $1{ }^{\circ} \mathrm{C}$ above those in the 1960s. The modeled mass balance of Glaciar Marinelli has been predominantly negative since the early 1990 s.
The $13 \mathrm{~km}$ of retreat since 1960 and the presence of high, fresh trimlines clearly indicate that Glaciar Marinelli has been shrinking by both surface lowering and retreat over the past half-century, in part due to negative mass balance in the past few decades and likely also due to longitudinal extension of the glacier as calving rates increased during retreat. Noting that the longitudinal profile of the glacier surface tends to be roughly maintained but shifts up-valley during retreat, the temporal variability in the rate of glacier thinning can be assessed from the retreat history and trimlines on the valley walls. To first order, the thinning rate at any point on the glacier equals the retreat rate multiplied by the local surface slope, and hence thinning rates decrease up-glacier from the terminus. To estimate the rate of ice-volume decrease reflected in the thinning, we assume that the thinning rate equals the product of the retreat rate and surface slope of the glacier in the ablation area, and then decreases up-glacier to vanishing values at the glacier headwall. $Q_{\text {thin }}$ slowly increased from $0.05 \mathrm{~km}^{3} \mathrm{a}^{-1}$ in 1950 to $0.7 \mathrm{~km}^{3} \mathrm{a}^{-1}$ during the period of most rapid retreat in 1997, then decreased to $0.2 \mathrm{~km}^{3} \mathrm{a}^{-1}$ in 2005 (Fig. 8a).

The volume of ice lost annually by Glaciar Marinelli due to its length change $\left(Q_{\text {term }}\right)$ since it began to retreat can be estimated from the subsurface bathymetry and retreat rate. The volume of ice lost below sea level since 1960 is $3.3 \mathrm{~km}^{3}$. Assuming that the ice surface at the terminus averaged $40 \mathrm{~m}$ a.s.l. across the ice front, Glaciar Marinelli lost a total of $4.4 \mathrm{~km}^{3}$ of ice from the glacier snout between 1960 and 2005, in excess of the ice lost due to calving and melting while the calving front is stationary. This 'additional' ice flux delivered to and lost from the terminus averaged $0.1 \mathrm{~km}^{3} \mathrm{a}^{-1}$; it accelerated markedly in the 1990s to a peak of $0.4 \mathrm{~km}^{3} \mathrm{a}^{-1}$ in 1997 , and has been steadily decreasing since (Fig. 8a).

Due to the loss of ice from the glacier front as it retreated and the glacier thinned, Glaciar Marinelli has shrunk by an average of $0.26 \mathrm{~km}^{3} \mathrm{a}^{-1}$ over the latter half of the 20th century. For comparison, on average only $0.21 \mathrm{~km}^{3} \mathrm{a}^{-1}$ has been lost to ablation during the past 50 years. Together, these volumetric losses from the glacier have vastly outpaced the input of snow since the initiation of retreat in the early 1970s, which steadily decreased to average only $0.29 \mathrm{~km}^{3} \mathrm{a}^{-1}$ in the past decade (Fig. 8a). The resulting calving flux increased from 0.3 to $1.25 \mathrm{~km}^{3} \mathrm{a}^{-1}$ from the late $1970 \mathrm{~s}$ to the mid-1990s, then 


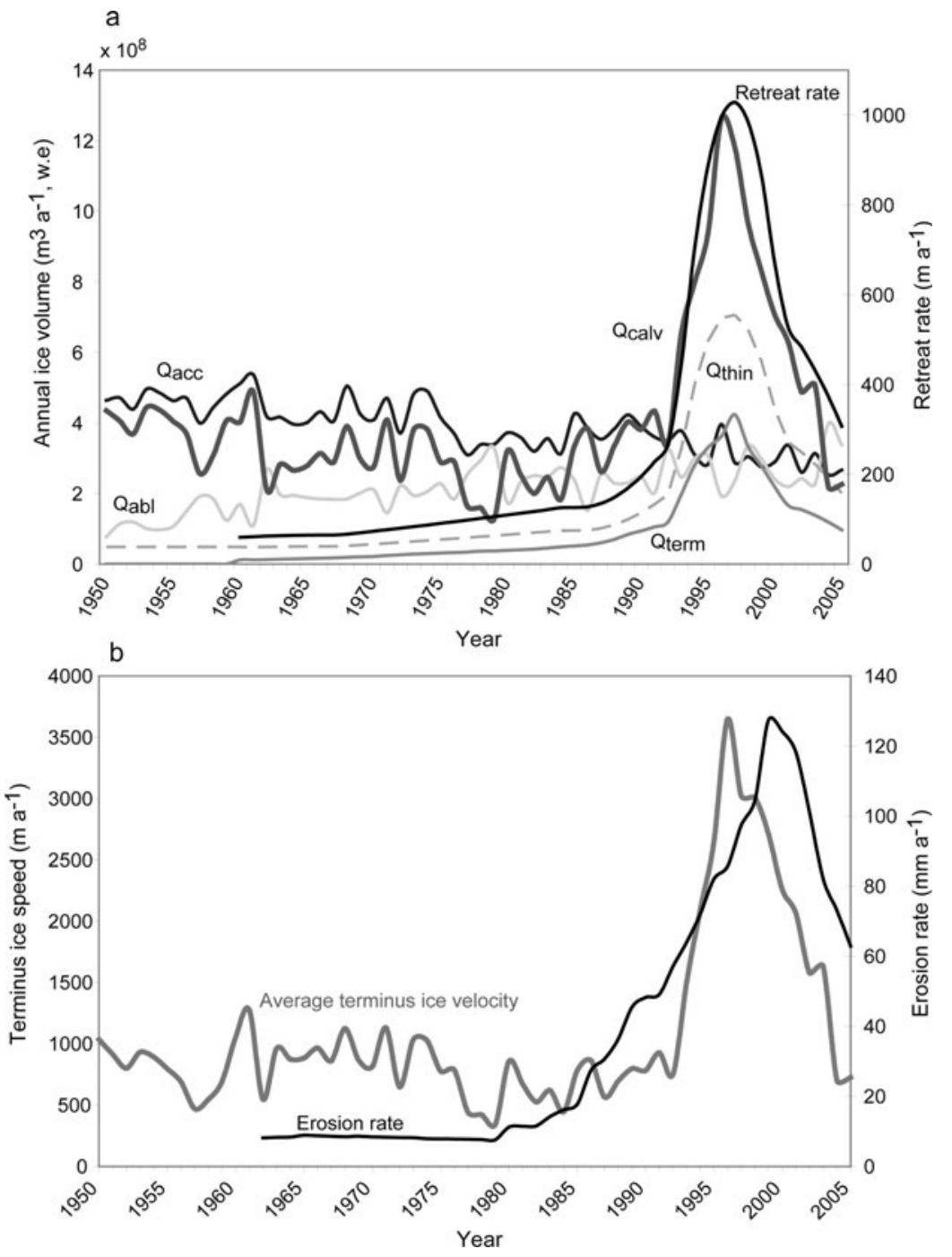

Fig. 8. Ice addition to and loss from Glaciar Marinelli from 1950 to 2005 , expressed as ice volumes in $\mathrm{m}^{3}$ w.e. $\mathrm{a}^{-1}$. (a) The annual snow input $Q_{\text {acc }}$ (black curve), annual ablation loss $Q_{\text {abl }}$ (light grey curve), annual volume of ice lost to thinning $Q_{\text {thin }}$ (dashed grey curve), volume of ice lost from the terminus due to retreat $Q_{\text {term }}$ (grey curve), and the resulting calving flux $Q_{\text {calv }}$ (dark grey curve) compared to retreat rate (black curve). (b) The annual cross-sectionally averaged ice speed at the terminus (i.e. $Q_{\text {calv }}$ divided by the terminus cross-sectional area) (grey curve), and the annual erosion rate (black curve).

dropped to $0.4 \mathrm{~km}^{3} \mathrm{a}^{-1}$ in the $21 \mathrm{st}$ century (due in part to the sharp deceleration of retreat after 1997). Expressed as a crosssectionally averaged calving velocity in Figure $8 \mathrm{~b}$, ice speeds at the terminus increased from $500-1000 \mathrm{~m} \mathrm{a}^{-1}$ in the mid1970 s to a peak of $>3 \mathrm{~km} \mathrm{a}^{-1}$ in the late 1990s, during the same period when erosion rates were accelerating rapidly. Maximum ice speeds appear to peak a couple of years prior to the peak in erosion rate. Exploring the cross-correlation between annual erosion rates and terminus ice speeds suggests a best fit when erosion lagged 2 years behind the sliding speed $\left(r^{2}=0.72\right.$, versus $r^{2}=0.65$ if no lag is assumed). Whether this lag is significant is unknown, however, because of the large uncertainties in the ice budget.

These results suggest that the strong negative mass balance of Glaciar Marinelli since the early 1970s resulted in rapid basal ice motion that fueled two decades of unusually rapid erosion. The subsequent decrease in calving flux, due to slowing retreat after 1997, in turn slowed basal ice motion and, after a 2 year lag, contributed to a reduction in the rate of erosion of the basin from $120 \mathrm{mma}^{-1}$ to $60 \mathrm{~mm} \mathrm{a}^{-1}$ in the 21 st century (Fig. 8b).

\section{DISCUSSION}

\subsection{Controls on calving}

Once retreat was underway after 1967, the pace of ice loss at the terminus accelerated markedly, in particular in the mid-1990s following a period when ablation exceeded accumulation considerably. As mentioned earlier, the calving flux and, according to the ice budget model, the terminus ice speeds increased dramatically during the mid1980s to the mid-1990s (Fig. 8b), suggesting that the glacier was rapidly losing mass through both anomalously rapid melting and calving. As the terminus first retreated into deeper water in the 1960s and was subjected to increased submarine melting and more rapid calving (e.g. Pelto and Warren, 1991; Motyka and others, 2003), calving rates increased sharply, contributing to the rapid frontal retreat. Interestingly, although the ice front retreated into increasingly deeper water from the mid-1960s to the early 1980s, the calving rate appears to have remained steady or even slowed, suggesting no strong correlation between water depth and calving rate for this glacier. Although the trend of 
strongly negative mass balance continued to 2005, both retreat rates and calving rates decreased after peaking in 1997, due in part to the emergence of almost half of the terminus onto land.

The marked increase in both the rate of retreat and the ice flux to the terminus of Glaciar Marinelli in the mid-1990s appears to be caused by a period of unfavorable climate in the past few decades, and not simply by changing topographic conditions at the ice front, as was previously suggested (Holmlund and Fuenzalida, 1995; Porter and Santana, 2003). While the area of the ice front subject to submarine melt and calving slowly increased from 2 to $4 \times 10^{5} \mathrm{~m}^{2}$ from 1967 to 1989 , it decreased again starting in 1989 to only $2.3 \times 10^{5} \mathrm{~m}^{2}$ in 2005 , a period during which both retreat and calving rates were accelerating. Water depth at the ice front did not change appreciably during this period, with the exception of a narrow bedrock knob that the terminus passed over quite rapidly in 1997. Changing submarine melt conditions at the glacier terminus were evidently not driving retreat rates.

Intriguingly, neighboring glaciers in the Cordillera Darwin that are not calving but terminate on land have been relatively stable and few have slowly advanced during the same period (Holmlund and Fuenzalida, 1995; personal communication from C. Porter, 2006). This contrast in response to similar climatic forcing suggests that valley morphology and the presence or absence of a maritime sink of ice are the dominant controls on glacier stability in this region. Without a deep fjord in which to calve and lose ice, our ice budget model for Glaciar Marinelli suggests that, until the mid-1990s, the snow input continuously exceeded the loss to ablation, and the glacier could have remained stable or even advanced. That several of the other landterminating glaciers of the Cordillera Darwin have advanced helps us generate confidence in our modeled ice budget, though we note that significant uncertainties remain.

\subsection{Implications for erosion over glacial cycles}

The sustained average erosion rate of $39 \pm 16 \mathrm{~mm} \mathrm{a}^{-1}$ over the past 50 years is extremely rapid, particularly given the size and relief of the Marinelli basin. In the absence of significant rock uplift, for example, such rapid erosion applied to Monte Shipton, located at the head of the basin and $2469 \mathrm{~m}$ a.s.l., would remove it in only $63 \mathrm{kyr}$. Maximum Quaternary tectonic uplift rates in the region have been estimated at $1 \mathrm{~mm} \mathrm{a}^{-1}$ (e.g. Diraison and others, 1997). Such rapid erosion therefore cannot be sustained in the long term, or the Cordillera Darwin massif would have been flattened within one glacial cycle. These rates must reflect a short-lived period of rapid transfer of glacial ice from the highlands to the ocean and, correspondingly, rapid erosion. Similarly, the rapid glacier thinning and recession observed at Glaciar Marinelli must also be highly unusual, for at recent rates of retreat ( $>13 \mathrm{~km}$ in 50 years) and thinning ( $>200 \mathrm{~m}$ in 50 years) there would be no ice remaining in the basin within a century. We stress that this result, $39 \pm 16 \mathrm{~mm} \mathrm{a}^{-1}$ over the past 50 years, is robust and based simply on sediment volumes in Marinelli fjord determined from seismic profiles and the known retreat history; it is independent of any aspect of our sedimentation and ice budget models.

Since much of a normal tidewater glacier cycle is spent in a quasi-stable mode (Meier and Post, 1987), the phase of rapid retreat, ice motion and associated erosion, such as we are currently observing at Glaciar Marinelli, tends to be relatively short. During the much longer advance phase, the glacier must first evacuate the proglacial and subglacial sediment collected in the basin before it can erode its basin anew. Although total sediment yields would be high during such an advance due to evacuation of subglacial sediments, the bedrock would be shielded from erosion as long as it is overlain by sediments. The most representative measure of glacial erosion rate for the entire advance-retreat cycle would therefore be the rate during a quasi-stable phase at the end of a period of protracted advance or retreat, when the glacier had already evacuated any proglacial sediment that would be shielding the bed, and prior to the period of fast flow characteristic of the rapid retreat phase.

In the absence of a quantitative measure of sediment yields from Glaciar Marinelli during this quasi-stable phase, the last of which culminated prior to 1960, we can estimate this long-term erosion rate to be $\sim 10 \pm 3 \mathrm{~mm} \mathrm{a}^{-1}$ by an extrapolation of a linear regression of erosion rates calculated on an annual basis as a function of retreat rate, to periods when there was no retreat (extrapolation of curve in Fig. 5b). This estimated long-term erosion rate is one-quarter of the measured erosion rates over the past few decades. While significantly less than contemporary erosion rates, it is important to note that this estimate of long-term glacial erosion remains an order of magnitude greater than the highest plausible tectonic uplift rates in the region (e.g. Diraison and others, 1997), and hence could not be sustained throughout the Quaternary or else the Cordillera Darwin would have been removed completely.

Both the recent and long-term sediment yields and erosion rates at Glaciar Marinelli are amongst the highest reported rates worldwide, similar to those of the largest Alaskan tidewater glaciers, many of which have also experienced drastic retreat, but which are located in a considerably more active tectonic setting (e.g. Powell, 1991; Hallet and others, 1996; Koppes and Hallet, 2002, 2006). The similarity in the correlation between rapid erosion and glacier retreat in both hemispheres suggests that this correlation is universal for retreating tidewater glaciers. As these glaciers are all responding to a century of exceptionally rapid warming following the end of the LIA, the unusually rapid ice motion typical of the retreat phase most probably biases all recent rates of erosion by tidewater glaciers. The discrepancy between erosion rates and uplift rates in both of these regions underscores the transient state of such glaciated landscapes.

\section{CONCLUSIONS}

Glaciar Marinelli has retreated almost $13 \mathrm{~km}$ and thinned by $\sim 200 \mathrm{~m}$ since 1960, a period of gradually increasing temperatures and decreasing precipitation. Retreat rates varied from $100 \mathrm{~m} \mathrm{a}^{-1}$ in 1960 to a peak exceeding $1 \mathrm{~km} \mathrm{a}^{-1}$ in the mid-1990s, and have since decreased. This rapid reduction in glacier volume results from much more ice being conveyed to the glacier front and lost by calving and melting than can be sustained by the input of snow. Estimated cross-sectionally averaged ice speeds increased from $\sim 500 \mathrm{~m} \mathrm{a}^{-1}$ in 1960 to $>3 \mathrm{~km} \mathrm{a}^{-1}$ in the late 1990s, before slowing to $1 \mathrm{~km} \mathrm{a}^{-1}$ in the $21 \mathrm{st}$ century. For Glaciar Marinelli, as for many other heavily glaciated basins in coastal areas, the recent period of warming and rapid retreat coincides with a significant increase in the ice flux to the terminus and, by reasonable inference, in the rate of basal sliding. 
Annual basin-wide erosion rates have paralleled retreat rates and inferred sliding speeds, increasing from $<10 \mathrm{~mm} \mathrm{a}^{-1}$ in the $1960 \mathrm{~s}$ to $>120 \mathrm{~mm} \mathrm{a}^{-1}$ in the late $1990 \mathrm{~s}$. Sliding speeds account for $72 \%$ of the observed variations in erosion rate since 1960, with a hint of a 2 year lag that may reflect the characteristic time needed to evacuate most of the debris produced when the glacier was most active. Erosion rates averaged $39 \mathrm{~mm} \mathrm{a}^{-1}$ over the last 45 years, which is about four times faster than when the glacier is stable, neither retreating nor advancing. Our finding that contemporary glacial erosion rates exceed $10 \mathrm{~mm} \mathrm{a}^{-1}$ and increased as Glaciar Marinelli retreated rapidly in the latter half of the 20th century matches results from two tidewater glaciers in Alaska, Muir and Tyndall Glaciers (Koppes and Hallet, 2002, 2006). The similarities in basin-wide erosion rates calculated from sediment-yield data from a number of glaciers in two different hemispheres suggest that, in general, contemporary erosion rates for fast-moving temperate tidewater glaciers are very high, far exceeding tectonic uplift rates. They also indicate that erosion rates over the last few decades greatly exceed those over the entire glacier advance-retreat cycle, most probably because of the exceptionally rapid ice motion during this period of rapid glacier thinning and retreat.

The erosion rates measured for these glaciers on timescales ranging from 1 to 50 years, as well as estimated long-term erosion rates that reflect a significant decrease in erosion rates during glacier standstills and advances, remain among the highest known basin-wide erosion rates worldwide. Significantly, this rapid recent glacial erosion is found in a wide range of climatic, geologic and tectonic settings; hence it is not due to the substrates being unusually erodible because of inherently weak lithologies or pervasive fracturing along fault zones, as has been suggested in studies of erosion in Alaska.

\section{ACKNOWLEDGEMENTS}

We thank C. Porter and B. Hall for downloading and retrieving the weather gauges, J. Smith-Wellner for help collecting the seismic profiles, Captain Robert and the crew of MV/IB Nathaniel B. Palmer for access to Marinelli fjord and for use of MV Cajun Cruncher in the inner fjord, and $\mathrm{H}$. Greenberg for assistance with Geographic Information System analysis. We also thank C. Schneider for access to unpublished ablation measurements on Glaciar Lengua. This work was funded by US National Science Foundation Office of Polar Programs grant No. 03-338371.

\section{REFERENCES}

Anderson, J.B. 1999. Antarctic marine geology. Cambridge, etc., Cambridge University Press.

Bentley, M.J. and R.D. McCulloch. 2005. Impact of neotectonics on the record of glacier and sea level fluctuations, Strait of Magellan, Southern Chile. Geogr. Ann., Ser. A, 87(2), 393-402.

Berger, A.L. and J.A. Spotila. 2008. Denudation and deformation in a glaciated orogenic wedge: the St. Elias orogen, Alaska. Geology, 36(7), 523-526.

Brown, C.S., M.F. Meier, and A. Post. 1982. Calving speed of Alaska tidewater glaciers, with application to Columbia Glacier. USGS Prof. Pap. 1258-C, C1-C13.

Brozović, N., D.W. Burbank and A.J. Meigs. 1997. Climatic limits on landscape development in the northwestern Himalaya. Science, 276(5312), 571-574.

Carrasco, J., G. Casassa and A. Rivera. 2002. Meteorological and climatological aspects of the Southern Patagonia Icefield. In
Casassa, G., F. Supúlveda and R. Sinclair, eds. The Patagonian ice fields: a unique natural laboratory for environmental and climate change studies. New York, Kluwer Academic/Plenum Publishers, 29-41.

Cowan, E.A. and R.D. Powell. 1991. Ice-proximal sediment accumulation rates in a temperate glacial fjord, southeastern Alaska. Geol Soc. Am. Spec. Pap. 261, 61-73.

Dalziel, I.W.D. and R. Cortés. 1972. Tectonic style of the southernmost Andes and the Antarctandes. In Gill, J.E., ed. 24th International Geological Congress, Montreal, Canada. Section 3: Tectonics. Montréal, International Geological Congress, 316-327.

Diraison, M., P.R. Cobbold, D. Gapais and E.A. Rossello. 1997. Magellan Strait: part of a Neogene rift system. Geology, 25(8), 703-706.

Escobar, F., F. Vidal, C. Garín and R. Naruse. 1992. Water balance in the Patagonia icefield. In Naruse, R. and M. Aniya, eds. Glaciological researches in Patagonia, 1990. Nagoya, Japanese Society of Snow and Ice. Data Center for Glacier Research, 109-119.

Gulick, S., J. Jaeger, J. Freymueller, P. Koons, T. Pavlis and R. Powell. 2004. Examining tectonic-climatic interactions in Alaska and the northeastern Pacific. Eos, 85(43), 433, 438-439.

Gurnell, A.M., D. Hannah and D. Lawler. 1996. Suspended sediment yield from glacier basins. IAHS Publ. 236 (Symposium at Exeter 1996 - Erosion and Sediment Yield: Global and Regional Perspectives), 97-104.

Hallet, B. 1979. A theoretical model of glacial abrasion. J. Glaciol., 23(89), 39-50.

Hallet, B. 1996. Glacial quarrying: a simple theoretical model. Ann. Glaciol., 22, 1-8.

Hallet, B., L.E. Hunter and J. Bogen. 1996. Rates of erosion and sediment evacuation by glaciers: a review of field data and their implications. Global Planet. Change, 12(1-4), 213-235.

Harbor, J. and J. Warburton. 1993. Relative rates of glacial and nonglacial erosion in Alpine environments. Arct. Alp. Res., 25(1), $1-7$.

Holmlund, P. and H. Fuenzalida. 1995. Anomalous glacier responses to 20th century climatic changes in Darwin Cordillera, southern Chile. J. Glaciol., 41(139), 465-473.

Howat, I.M., I. Joughin, S. Tulaczyk and S. Gogineni. 2005. Rapid retreat and acceleration of Helheim Glacier, east Greenland. Geophys. Res. Lett., 32(22), L22502. (10.1029/2005GL024737.)

Humphrey, N.F. and C.F. Raymond. 1994. Hydrology, erosion and sediment production in a surging glacier: Variegated Glacier, Alaska, 1982-83. J. Glaciol., 40(136), 539-552.

Humphrey, N., B. Kamb, M. Fahnestock and H. Engelhardt. 1993. Characteristics of the bed of the lower Columbia Glacier, Alaska. J. Geophys. Res., 98(B1), 837-846.

Hunter, L.E., R.D. Powell and D.E. Lawson. 1996. Flux of debris transported by ice at three Alaskan tidewater glaciers. J. Glaciol., 42(140), 123-135.

Kalnay, E. and 21 others. 1996. The NCEP/NCAR 40-year reanalysis project. Bull. Am. Meteorol. Soc., 77(3), 437-471.

Kamb, B. and 7 others. 1985. Glacier surge mechanism: 19821983 surge of Variegated Glacier, Alaska. Science, 227(4686), 469-479.

Kamb, B., H. Engelhardt, M.A. Fahnestock, N. Humphrey, M. Meier and D. Stone. 1994. Mechanical and hydrologic basis for the rapid motion of a large tidewater glacier. 2. Interpretation. J. Geophys. Res., 99(B8), 15,231-15,244.

Kistler, R. and 12 others. 2001. The NCEP/NCAR 50-year reanalysis: monthly means CD-ROM and documentation. Bull. Am. Meteorol. Soc., 82(2), 247-267.

Koppes, M.N. and B. Hallet. 2002. Influence of rapid glacial retreat on the rate of erosion by tidewater glaciers. Geology, 30(1), 47-50.

Koppes, M. and B. Hallet. 2006. Erosion rates during rapid deglaciation in Icy Bay, Alaska. J. Geophys. Res., 111(F2), F02023. (10.1029/2005JF000349.) 
Luckman, A., T. Murray, R. de Lange and E. Hanna. 2006. Rapid and synchronous ice-dynamic changes in East Greenland. Geophys. Res. Lett., 33(3), L03503. (10.1029/2005GL025428.)

Meier, M.F. and A. Post. 1987. Fast tidewater glaciers. J. Geophys. Res., 92(B9), 9051-9058.

Meigs, A. and J. Sauber. 2000. Southern Alaska as an example of the long-term consequences of mountain building under the influence of glaciers. Quat. Sci. Rev., 19(14-15), 1543-1562.

Mitchell, S.G. and D.R. Montgomery. 2006. Influence of a glacial buzzsaw on the height and morphology of the Cascade Range in central Washington State, USA. Quat. Res., 65(1), 96-107.

Molnia, B.F., T.J. Atwood, P.R. Carlson, A. Post and S.C. Vath. 1984 Map of marine geology of Upper Muir and Wachusett inlets, Glacier Bay, Alaska; sediment distribution and thickness, bathymetry, and interpreted seismic profiles. USGS Open File Rep. 84-632.

Montgomery, D.R., G. Balco and S.D. Willett. 2001. Climate, tectonics, and the morphology of the Andes. Geology, 29(7), 579-582.

Motyka, R.J., L. Hunter, K.A. Echelmeyer and C. Connor. 2003. Submarine melting at the terminus of a temperate tidewater glacier, LeConte Glacier, Alaska, U.S.A. Ann. Glaciol., 36, 57-65.

Pelto, M.S. and C.R. Warren. 1991. Relationship between tidewater glacier calving velocity and water depth at the calving front. Ann. Glaciol., 15, 115-118.

Porter, S.C. 1981. Pleistocene glaciation in the southern Lake District of Chile. Quat. Res., 16(3), 263-292.

Porter, S.C. and A. Santana. 2003. Rapid 20th century retreat of Ventisquero Marinelli in the Cordillera Darwin Icefield. An. Inst. Patagonia, 31, 17-26.

Powell, R.D. 1991. Grounding-line systems as second-order controls on fluctuations of tidewater termini of temperate glaciers. Geol. Soc. Am. Spec. Pap. 261, 75-93.
Rabassa, J. and 6 others. 1992. The Quaternary of Tierra del Fuego, Argentina: the status of our knowledge. Sver. Geol. Unders. 81 249-256.

Riihimaki, C.A., K.R. MacGregor, R.S. Anderson, S.P. Anderson and M.G. Loso. 2005. Sediment evacuation and glacial erosion rates at a small alpine glacier. J. Geophys. Res., 110(F3), F03003. (10.1029/2004JF000189.)

Rosenblüth, B., G. Casassa and H. Fuenzalida. 1995. Recent climatic changes in western Patagonia. Bull. Glacier Res. 13, 127-132.

Schneider, C. and D. Gies. 2004. Effects of El Niño-Southern Oscillation on southernmost South America precipitation at $53^{\circ} \mathrm{S}$ revealed from NCEP-NCAR reanalyses and weather station data. Int. J. Climatol., 24(9), 1057-1076.

Schneider, C., R. Kilian and M. Glaser. 2007. Energy balance in the ablation zone during the summer season at the Gran Campo Nevado Ice Cap in the Southern Andes. Global Planet. Change, 59(1-4), 175-188.

Sheaf, M.A., L. Serpa and T.L. Pavlis. 2003. Exhumation rates in the St. Elias Mountains, Alaska. Tectonophysics, 367(1-2), 1-11.

Spotila, J.A., J.T. Buscher, A.J. Meigs and P.W. Reiner. 2004. Longterm glacial erosion of active mountain belts: example of the Chugach-St. Elias Range, Alaska. Geology, 32(6), 501-504.

Stoker, M.S., J.B. Pheasant and H. Josenhans. 1997. Seismic methods and interpretation. In Davies, T.A. and 7 others, eds. Glaciated continental margins: an atlas of acoustic images. London, Chapman \& Hall, 9-26.

Stravers, J.A., G.H. Miller and D.S. Kaufman. 1992. Late glacial ice margins and deglacial chronology for southeastern Baffin Island and Hudson Strait, eastern Canadian Arctic. Can. J. Earth Sci., 29(5), 1000-1017.

Syvitski, J.P.M. 1989. On the deposition of sediment within glacierinfluenced fjords: oceanographic controls. Mar. Geol., 85(2-4), 301-329.

Van der Veen, C.J. 1996. Tidewater calving. J. Glaciol., 42(141), $375-385$.

MS received 29 October 2008 and accepted in revised form 6 January 2009 